\title{
Suggested Syllabus for World Englishes and Culture Elective Course at ELT Departments
}

\author{
${ }^{\mathrm{a}}$ Kürşat Cesur (iD and ${ }^{\mathrm{b}}$ Sezen Balaban \\ a Assist. Prof. Dr., Çanakkale Onsekiz Mart University, Çanakkale, Turkey, kursatcesur@ comu.edu.tr \\ b Instructor, Uludağ University, Bursa, Turkey, balaban@uludag.edu.tr
}

To cite this article: Cesur, K. \& Balaban, S. (2020). Suggested syllabus for World Englishes and culture elective course at ELT departments. Focus on ELT Journal (FELT), 2(1), 37-47. https://doi.org/10.14744/felt.2020.00017

\begin{abstract}
The Council of Higher Education (CoHE) transformed the curriculum for teaching departments into a phase during which more elective courses are taught in recent years. In accordance with this, the related innovation led to the constitution of three essential elective categories named as professional teaching knowledge (PTK), subject area knowledge (SAK) and general knowledge (GK). This research study aimed to investigate and suggest the integration of World Englishes (WE) and Culture course into English Language Teaching undergraduate programme. This study initially targeted to investigate teacher trainers' views on the most avail contents to integrate within the WE and Culture course. Subsequent to this aim, the study aimed to constitute a syllabus for this course. With this notion, a study which incorporated two distinct stages was generated. The study followed a mixed method sequential exploratory research design. Correspondingly, documents which embrace books, university syllabi, google search documents and research articles were analyzed. Following this execution, a survey was constituted and conducted on teacher trainers. After analyzing the documents, SPSS (Statistical Package for Social Sciences) 21.0 was employed for the analysis of the quantitative findings. Results of the study demonstrated that there were 34 essential topics which were drawn from the analysis of the documents and teacher trainers favored some of these topics more than the others. A syllabus for "World Englishes and Culture" course was suggested at the end of the study.
\end{abstract}

\section{Introduction}

The concern of World Englishes (WE) has been a substantial issue in Applied Linguistics and ELT (Kuo, 2006). The reason for this argument can be that diversity in English language is considerable. To explain, English language has been utilized within environments of distinct geographies and histories. In addition to this, the diversity and variety in English use arise from the purpose of this language use. It could be observed that there exist people who employ English for professional aims and others who perform it for daily conversations. From this view, it has been suggested that English should be considered as a global language. In accordance with this view, it has been argued that World Englishes should be allowed to progress in their own context, which could additionally accept the distinctions of these English varieties from the so-called 'standard' English. 


\section{Background of the Study}

Language education in Turkey has been exposed to distinct aspects of transformation since an engagement with the European Union (EU) criteria and Bologna Process came into prominence. Council of Higher Education (CoHE) undertook the most recent innovations in language teaching programmes in 1997, 2006 and lastly in 2018. Additionally, some arrangements were done in terms of professional teaching knowledge (PTK) and general knowledge (GK) courses in 2016. Furthermore, additional courses were identified and authorized as supplemental to the obligatory courses. Consequently, it was specified that subject area knowledge (SAK) courses would comprise over half of the programme, PTK would be involved within almost one-third and GK courses would be included within nearly one-fourth of the programme. In addition to this, the final innovation COHE put into practice in 2018 raised concerns such as the categorization of elective courses, a formation of a common core curriculum and an enhancement in the number of elective courses.

\section{Aim of the Study and Research Questions}

Investigating distinct university syllabi and other documents, this study comprising two stages aimed at obtaining the most frequently employed contents of WE and Culture course and views by teacher trainers and accordingly suggesting an ideal WE and Culture course syllabus for ELT departments of education faculties. To this end, the answers to two discrete research questions below were investigated:

RQ1: What are the most-preferred World Englishes (WE) and Culture course topics in ELT departments at education faculties in Turkey?

RQ2: What are the most-preferred World Englishes (WE) and Culture course topics favored by the teacher trainers?

\section{Significance of the Study}

The significance of this study emerges from discrete aspects. Primarily, this study aimed at exploring previous studies in literature on the use of WE and Culture course. In accordance with this, specific research through providing the current WE and Culture syllabi in Turkey was targeted. Furthermore, almost no research has been implemented so as to offer a syllabus to teachers or institutions on "WE and Culture". Additionally, this research aspires to generate and enhance an awareness of the WE issue through designating teachers, teacher candidates, learners and institutions about the diversities and varieties in English as a global language.

\section{Limitations of the Study}

This research study comprised of two distinct data collection stages. In the initial stage, content analysis of university syllabi was generated; however, there still exist some institutions whose syllabus could not been attained and therefore not analyzed. Another limitation could be specified as the number of teacher trainers who responded to the survey. In other words, 63 teacher trainers from ELT departments responded the survey. A greater number of participants could have changed the findings on the most-preferred WE and Culture course topics. One further limitation could be indicated as the deficiency of an item in the quantitative part which would question whether an elective course named as 'WE and Culture' is needed for undergraduate ELT learners. 


\section{Literature Review}

Conceiving its history, it was specified that English has transformed from a local language which was utilized on an island into a global language which is spoken, taught and needed all over the world (Kachru \& Nelson, 2001). According to Kachru (1985), whose Concentric Circle Model has been a definition of World Englishes, inner circle countries comprise The United Kingdom, America, Canada, Australia, and New Zealand; outer circle countries embrace India, Nigeria, etc.; and expanding circle countries include China, France, Israel, Egypt, etc. The researcher states that it is specifically the expanding countries group within this model which construes English as a world language.

World Englishes (WE) or English as a Lingua Franca (ELF) concern has been a crucial matter of research and debate by several researchers. This research and debate put ideological concerns into prominence. From Cogo and Dewey's (2012) view, it was argued that English should be utilized as a representative of flexibility. Additionally, Cogo and Dewey (2012) related WE to matters of pluricentrism and multilingualism. On the other hand, Kachru and Nelson (2001) stated that WE has generated new dimensions both linguistically and pedagogically.

In addition to the theoretical perspectives to WE, a pedagogical aspect of this concern led practitioners to involve this issue as a specific course at ELT department of universities. With a review of literature, a considerable amount of research studies which were implemented on the integration of WE into university syllabi exist. One research study was implemented by Tanghe (2014) in South Korea. The aim of this experiment was to provide progress in students' conversational skills, generate awareness on learners about WE and enhance their critical thinking skills. Two classes which participated in this study were exposed to WE course for 15 weeks each session of which lasted for 110 minutes. Findings demonstrated that WE course assisted learners to progress their confidence in performing English. Furthermore, they gained a wider perspective of English and a further understanding mindset towards the varieties of this global language. Additionally, they owned a positive attitude towards the future use of technology and blogs in English teaching.

A further study was generated by Bayne, Usui and Watanabe (2002) with the aim of considering English from discrete dimensions. To this end, video courses on WE were employed within 9-10 weeks so as to encourage learners' progress in both communication skills and other language skills such as writing, organization, synthesis and word knowledge. The experiment was supported by the application of learner performances, and pre- $\&$ postquestionnaires. Findings showed that learners reflected positive responses about their WE training. A striking comment specified by one of the learners was that there was no one true English.

An additional study addressed WE concern from a literature basis (Sridhar, 1982). This study aimed to highlight the significance of non-native literary texts for ESL teaching. Accommodating several pieces of literature from distinct non-native cultures, the researcher intended to specify that it was an English teacher's mission to teach this global language through embracing traditions, native cultures, customs and social issues. It was stated that a language teaching profession is deficient unless these concerns are instructed to learners in addition to linguistic concerns. As a consequence, this paper aims to elaborate the content of 
World Englishes and Culture course for ELT departments and it was aimed to offer stakeholders of ELT world various suggestions on generating a WE syllabus.

\section{Methodology}

Research Design

A mixed-methods research design (Creswell, 2014) was implemented so as to generate this research study. The first stage of the study comprised of content analysis of the data collected from the documents. Set of analytic activities proposed by Lune and Berg (2017) while analyzing the data was followed. University syllabi, books, research articles and other documents explored in Google were investigated in order to constitute the items of a preplanned survey for teacher trainers. Subsequent to this stage, the possible contents to be included within the survey were ordered and composed a survey. In accordance with this, the survey was conducted on teacher trainers with the aim of exploring their views on an ideal WE and Culture syllabus. Therefore, both quantitative and qualitative means of data collection were utilized in this research study.

\begin{tabular}{|c|c|c|}
\hline Phase & Procedure & Products \\
\hline $\begin{array}{l}\text { Qualitative Data } \\
\text { Collection }\end{array}$ & \multirow[t]{2}{*}{$\begin{array}{l}\text { Universities, books, articles, google } \\
\text { documents }\end{array}$} & Syllabus contents \\
\hline$\downarrow$ & & \\
\hline $\begin{array}{c}\text { Qualitative } \\
\text { Data Analysis }\end{array}$ & \multirow[t]{2}{*}{$\begin{array}{l}\text { Thematic Analysis: Analysis of the } \\
\text { documents on WE and Culture }\end{array}$} & $\begin{array}{l}\text { Frequency Tables } \\
\text { Content Topics }\end{array}$ \\
\hline$\downarrow$ & & \\
\hline $\begin{array}{l}\text { Connecting Qualitative } \\
\text { and Quantitative Phases } \\
\downarrow\end{array}$ & Expert Opinion & $\begin{array}{l}\text { Final chart of contents to utilise a } \\
\text { quantitative data collection tool }\end{array}$ \\
\hline $\begin{array}{c}\downarrow \\
\text { QUANTITATIVE } \\
\text { Data Collection }\end{array}$ & \multirow[t]{2}{*}{ Questionnaire } & \multirow[t]{2}{*}{ Nominal (Categorical) item scores } \\
\hline$\downarrow$ & & \\
\hline $\begin{array}{l}\text { QUANTITATIVE } \\
\text { Data Analysis }\end{array}$ & \multirow[t]{2}{*}{ SPSS Descriptive Analysis } & \multirow[t]{2}{*}{ Questionnaire data results } \\
\hline$\downarrow$ & & \\
\hline $\begin{array}{l}\text { Integration of the } \\
\text { Quantitative and } \\
\text { Qualitative Results }\end{array}$ & $\begin{array}{l}\text { Interpretation and explanation of } \\
\text { QUAL \& QUAN results }\end{array}$ & $\begin{array}{l}\text { Conclusion, Discussion, Implications, } \\
\text { Future research }\end{array}$ \\
\hline \multicolumn{3}{|c|}{$\begin{array}{l}\text { Figure 1. Mixed Methods Sequential Exploratory Research Procedures } \\
\text { (Adapted from Ivankova et al., 2006, p. 16) }\end{array}$} \\
\hline \multicolumn{3}{|l|}{ Participants } \\
\hline \multicolumn{3}{|c|}{$\begin{array}{l}63 \text { teacher trainers from distinct universities in Turkey participated in the study. Subsequent } \\
\text { to the constitution of a survey by means of Google forms, these participants were expected to } \\
\text { conduct the survey through ordering the syllabus contents which they favored according to } \\
\text { their order of significance. No criteria were identified for the selection of participants except } \\
\text { for their profession; therefore, the participants were chosen using random sampling. In } \\
\text { addition to this, there was no specific research setting or location for the implementation of } \\
\text { this study since data collection procedure was generated by means of online research and } \\
\text { survey. }\end{array}$} \\
\hline
\end{tabular}




\section{Data Collection Instruments and Data Analysis}

Both qualitative and quantitative data collection processes were generated in this research study. The initial means of data collection embodied documents which were gathered from undergraduate ELT World Englishes and Culture course syllabi, books, articles, and other documents on World Englishes (WE) and Culture. 13 research articles, 18 documents from Google, two books and 21 university syllabi constituted the data collection tools to execute the first stage of the study. A qualitative thematic analysis was generated on these instruments using Microsoft Excel (Meyer \& Avery, 2009). Subsequent to the analysis of these documents, topics related to WE and Culture course were listed and formed a Likert Scale which encompassed items to rate from 1 to 5 (not at all important - very important). To analyze the data more specifically, the scale was identified within five categories ranging from 1.00-1.79 = not at all important, 1.80-2.59 = low importance, 2.60-3.39 = neutral, 3.40$4.19=$ important and 4.20-5.00 = very important (Hemmati \& Mojarrad, 2016). This means of data collection was formed and utilized so as to explore teacher trainers' views on WE and Culture course contents and their order of significance so as to compose a suggested course syllabus for undergraduate ELT programs. In accordance with this, mean scores over 4.20 were considered as highly suggested and therefore were specified within the results section.

\section{Results}

Findings below were obtained as a result of the reflection of two discrete research questions.

\section{World Englishes (WE) and Culture Course Topics Obtained from Content Analysis}

The first research question constituted the first section of the study and was reflected so as to investigate the most-preferred topics for World Englishes (WE) and Culture elective course at ELT undergraduate level. An analysis was generated by means of 13 research articles (coded as 'A'), two books (coded as 'B'), 18 documents from Google Search (coded as 'S') and 21 university syllabi (coded as ' $U$ '). As a result of this analysis through these data collection tools, the topics related to WE and Culture course were listed as demonstrated in Table 1. Among university syllabi which were incorporated in this study, merely the ones whose syllabus was explicitly specified and listed were indicated in Table In other words, 21 university syllabi were investigated; however, it was not all of these institutions which clearly exhibited their syllabus. 
Table 1. Findings obtained from content analysis

\begin{tabular}{|c|c|c|c|}
\hline TOPICS & $\mathrm{f}$ & $\%$ & *Codes \\
\hline 1. The effect of culture on language teaching & 23 & 43 & $\begin{array}{l}\text { A1, S2, S3, S4, S5, S6, S10, S12, S16, } \\
\text { S17, A12, A5, A7, A6, A2, A8, B1, B2, } \\
\text { U1, U2, U4, U6, U9 }\end{array}$ \\
\hline 2. English culture and history & 17 & 31 & $\begin{array}{l}\text { S1, S2, S3, S4, S5, S6, S11, S12, S13, } \\
\text { S14, S15, S16, S17, S18, A1, A2, U21 }\end{array}$ \\
\hline $\begin{array}{l}\text { 3. The use of English as an International Language } \\
\text { (EIL) }\end{array}$ & 15 & 28 & $\begin{array}{l}\text { S2, S3, S4, S5, S9, S10, S14, A3, A4, } \\
\text { A5, A6, U1, U2, U4, U6 }\end{array}$ \\
\hline 4. Internationalization: Standards of English & 15 & 28 & $\begin{array}{l}\text { A1, S2, S7, S8, S9, S10, S11, S15, S16, } \\
\text { S17, S18, A13, A9, A7, U21 }\end{array}$ \\
\hline $\begin{array}{l}\text { 5. Raising awareness on the relationship between } \\
\text { language and culture on students }\end{array}$ & 10 & 19 & $\begin{array}{l}\text { S10, S14, S15, A13, A9, A5, A6, U1, } \\
\text { U2, U4 }\end{array}$ \\
\hline 6. The effects of EIL on teacher training & 10 & 19 & $\begin{array}{l}\text { S2, S3, S5, S9, S10, S14, A3, A4, A5, } \\
\text { A6 }\end{array}$ \\
\hline $\begin{array}{l}\text { 7. Material analysis in terms of cultural elements } \\
\text { (coursebooks, literary texts, films, TV shows) }\end{array}$ & 9 & 17 & S5, S6, S16, U1, U2, U4, U6, U9, U11 \\
\hline 8. Sociocultural and Political Aspects of English & 7 & 13 & S1, S5, S6, S7, S12, S14, S18 \\
\hline 9. Multilingualism and Bilingualism & 7 & 13 & $\mathrm{~S} 10, \mathrm{~S} 14, \mathrm{~A} 1, \mathrm{~A} 5, \mathrm{~A} 6, \mathrm{~A} 7, \mathrm{~A} 10$ \\
\hline 10. Future of English & 6 & 11 & $\mathrm{~S} 10, \mathrm{~S} 13, \mathrm{~S} 15, \mathrm{~S} 18, \mathrm{~B} 2, \mathrm{U} 21$ \\
\hline 11. English, imperialism, and globalization & 5 & 9 & S5, A1, A10, A7, U21 \\
\hline 12. Kachru's Concentric Circle Model & 5 & 9 & S5, S15, A13, A9, A7 \\
\hline 13. Pidgins and Creoles & 4 & 7 & $\mathrm{~S} 10, \mathrm{~S} 17, \mathrm{~A} 2, \mathrm{~B} 2$ \\
\hline 14. Englishization and Nativization & 3 & 6 & $\mathrm{~A} 1, \mathrm{~A} 8, \mathrm{~B} 1$ \\
\hline 15. Language Policy & 3 & 6 & $\mathrm{~A} 6, \mathrm{~A} 7, \mathrm{~A} 10$ \\
\hline 16. Communicative Competence & 2 & 4 & A6, A7 \\
\hline $\begin{array}{l}\text { 17. Customs and language in modern western } \\
\text { societies }\end{array}$ & 1 & 2 & $\mathrm{U} 21$ \\
\hline 18. Customs and language in British society & 1 & 2 & $\mathrm{U} 21$ \\
\hline 19. Eastern societies and British society & 1 & 2 & $\mathrm{U} 21$ \\
\hline 20. Modern approaches to British culture & 1 & 2 & $\mathrm{U} 21$ \\
\hline $\begin{array}{l}\text { 21.The similarities and differences between the } \\
\text { students' own and cultures of the countries where } \\
\text { English is spoken }\end{array}$ & 1 & 2 & $\mathrm{U} 21$ \\
\hline $\begin{array}{l}\text { 22. The experience and perspective of people in the } \\
\text { countries and communities where the target } \\
\text { language is spoken }\end{array}$ & 1 & 2 & $\mathrm{U} 21$ \\
\hline $\begin{array}{l}\text { 23. Investigation of language with teachers from } \\
\text { local, national or international contexts }\end{array}$ & 1 & 2 & $\mathrm{U} 21$ \\
\hline $\begin{array}{l}\text { 24. Awareness of individual, (multi) cultural, and } \\
\text { psycho-social diversity in learning environments } \\
\text { and adapt to different local contexts }\end{array}$ & 1 & 2 & $\mathrm{U} 21$ \\
\hline $\begin{array}{l}\text { 25. Critical thinking on language-related issues } \\
\text { emerging from global English contexts }\end{array}$ & 1 & 2 & $\mathrm{U} 21$ \\
\hline 26. Examples of world Englishes & 1 & 2 & $\mathrm{U} 21$ \\
\hline 27. Introduction: Why 'world Englishes'? & 1 & 2 & $\mathrm{U} 21$ \\
\hline 28. English today: Error and innovation & 1 & 2 & $\mathrm{U} 21$ \\
\hline 29. African Englishes: How to write Africa & 1 & 2 & $\mathrm{U} 21$ \\
\hline 30. Asian Englishes: The Indian example & 1 & 2 & $\mathrm{U} 21$ \\
\hline 31. China: Limits on the acceptability of Englishes & 1 & 2 & $\mathrm{U} 21$ \\
\hline 32. Western culture during Renaissance & 1 & 2 & $\mathrm{U} 21$ \\
\hline 33. Industrial Era and British society & 1 & 2 & $\mathrm{U} 21$ \\
\hline 34. English literature and its linguistic development & 1 & 2 & $\mathrm{U} 21$ \\
\hline
\end{tabular}

*Code 'A' = Research articles, Code 'B' = Books, Code 'S' = Documents from Google Search, Code 'U' = University Syllabi 
As demonstrated in Table 1, findings reveal the frequency, percentage and codes of each preferred topic for WE and Culture as an elective course at undergraduate level. According to these findings, 'the effect of culture on language teaching' has the highest percentage which is nearly half of the analyzed documents. Furthermore, almost one-third (31\%) of the documents analyzed reveal that 'English culture and history' should be one of the WE and Culture syllabus topics. Over one-fourth (28\%) of the documents specify that 'the use of English as an international language (EIL)' and 'Internationalization: Standards of English' need to be involved in the course. The fifth most-frequent topics are 'raising awareness on the relationship between language and culture on students' and 'the effects of EIL on teacher training' with $19 \%$ frequency. The findings also reveal that 'material analysis in terms of cultural elements (course books, literary texts, films, TV shows)' is comprised within nine of the documents, six of which are university syllabi. Additionally, over one-tenth of the documents expose that 'sociocultural and political aspects of English' (13\%), 'multilingualism and bilingualism' (13\%) and 'future of English' (11\%) are preferred as topics related to WE and Culture elective course. Moreover, almost $10 \%$ of the documents introduce 'English, imperialism and globalisation' (9\%) and 'Kachru's Concentric Circle Model' (9\%) as alternative topics to the ones specified above. Four of the documents (7\%) consider 'Pidgins and Creoles' as preferred topic for the course. Merely three documents which involve articles and books highlights 'Englishization and Nativization' and 'language policy' $(6 \%)$ topics. 'Communicative competence' topic was embraced by two of the articles (4\%). The second half of Table 1 designates that the topics between 17 and 34 relate to one university syllabus (Hong Kong University), which has a frequency of $2 \%$.

\section{World Englishes (WE) and Culture Course Topics Favored by Teacher Trainers}

The second research question represented the second phase of this research study. By means of this question, it was aimed at investigating teacher trainers' order of significance in terms of the topics which they expected to be included in the syllabus of World Englishes (WE) and Culture as an elective course. As a result of responses obtained from 63 participants who responded to the survey, findings are demonstrated as in Table 2. Cronbach Alfa was identified as 0,886 which indicated high reliability for the survey to be used in the study (Büyüköztürk, 2006).

Table 2. Teacher trainers' order of significance among 35 topics

\begin{tabular}{lllllll}
\hline \multicolumn{1}{c}{$n=63$} & \multicolumn{5}{c}{$\mathrm{f}$} \\
\cline { 2 - 6 } & $* 1$ & 2 & 3 & 4 & $* 5$ & Mean \\
\hline 1.The effect of culture on language teaching & 1 & 0 & 4 & 9 & 49 & 4,67 \\
27. Introduction: Why 'world Englishes'? & 0 & 1 & 4 & 15 & 43 & 4,59 \\
5.Raising awareness on WE and culture & 0 & 0 & 4 & 20 & 39 & 4,56 \\
3.The use of English as an International Language EIL & 0 & 0 & 10 & 9 & 44 & 4,54 \\
26.Examples of World Englishes & 0 & 0 & 9 & 13 & 41 & 4,51 \\
25. Critical thinking on language-related issues emerging from & 1 & 2 & 7 & 12 & 41 & 4,43 \\
global English contexts & & & & & & \\
24. Awareness of diversity in learning environments and & 0 & 3 & 8 & 18 & 34 & 4,32 \\
adapting to different local contexts & & & & & & \\
6. Material analysis in terms of cultural elements (coursebooks, & 5 & 1 & 3 & 15 & 39 & 4,30 \\
literary texts, films, TV shows) & & & & & & \\
16.Communicative competence & 3 & 3 & 6 & 17 & 34 & 4,21 \\
7.Sociocultural and political aspects of English & 3 & 3 & 5 & 20 & 32 & 4,19 \\
10.The effects of EIL on teacher training & 3 & 3 & 8 & 16 & 33 & 4,16
\end{tabular}


21. The similarities and differences between the students' own and cultures of the countries where English is spoken

15.Language policy

12.Kachru's concentric circle model

4.Internationalization: Standards of English

22. The experience and perspective of people in the countries

and communities where the target language is spoken

35.WE in Popular Culture (Music, Newspapers,)

9.Future of English

23. Investigation of language with teachers from local, national or international contexts

2.English culture and history

8.Multilingualism and bilingualism

14.Englishization and nativization

34.Synthesizing Research on WE

28.English today Error and innovation

17.Customs and language in modern western societies

18.Customs and language in British society

13.Pidgins and creoles

19.Eastern societies and British society

30.Asian Englishes

20.Modern approaches to British culture

29.African Englishes

33.English literature and its linguistic development

32.Industrial era and British society

31.Western culture during renaissance

\begin{tabular}{llllll}
2 & 3 & 9 & 22 & 27 & 4,10 \\
0 & 5 & 12 & 19 & 27 & 4,08 \\
4 & 1 & 12 & 17 & 29 & 4,05 \\
1 & 3 & 15 & 18 & 26 & 4,03 \\
3 & 2 & 12 & 20 & 26 & 4,02 \\
& & & & & \\
0 & 5 & 15 & 17 & 26 & 4,02 \\
3 & 5 & 15 & 12 & 28 & 3,90 \\
2 & 9 & 9 & 18 & 25 & 3,87 \\
& & & & & \\
2 & 7 & 13 & 22 & 19 & 3,78 \\
4 & 8 & 13 & 15 & 23 & 3,71 \\
2 & 8 & 19 & 16 & 18 & 3,63 \\
7 & 3 & 17 & 18 & 18 & 3,59 \\
1 & 7 & 26 & 14 & 15 & 3,56 \\
3 & 11 & 14 & 24 & 11 & 3,46 \\
7 & 9 & 17 & 17 & 13 & 3,32 \\
3 & 12 & 24 & 16 & 8 & 3,22 \\
7 & 14 & 18 & 14 & 10 & 3,10 \\
8 & 13 & 21 & 13 & 8 & 3,00 \\
1 & 14 & 15 & 14 & 9 & 2,94 \\
9 & 14 & 21 & 11 & 8 & 2,92 \\
17 & 8 & 21 & 11 & 6 & 2,70 \\
24 & 15 & 13 & 8 & 3 & 2,22 \\
28 & 14 & 15 & 3 & 3 & 2,03 \\
\hline
\end{tabular}

*Teacher trainers were asked to rate the importance level of the topics from 1 to 5 (not at all important - very important).

According to Table 2, findings indicate that the most preferred topic for WE and Culture course is 'the effect of culture on language teaching' by 49 of the teacher trainers who found it very important. Additionally, 'Introduction: Why world Englishes?' is the second most preferred topic for the course which was identified with 4,59 mean score. Third, 'Raising awareness on WE and culture' was selected as very important by 39 of the participants (62\%). The fourth topic which was considered as very significant to 44 of the teacher trainers is 'The use of English as an international language'. 'Examples of WE' was selected as the fifth important topic for the course with a 4,51 mean value, which designates $65 \%$ of the participants. Furthermore, 'critical thinking on language-related issues emerging from global English contexts' was identified as the sixth most-preferred topic for the syllabus with the same percentage as 'Examples of WE'. Additionally, 'awareness of diversity in learning environments and adapting to different local contexts' was signified as another preferred topic with a percentage which is over half of the teacher trainers. 'Material analysis in terms of cultural elements' and 'communicative competence' were denoted by almost half of the participants.

On the other hand, the least-preferred three topics for the course were specified as 'English literature and its linguistic development', 'Industrial era and British society' and 'Western culture during renaissance'.

\section{Discussion}

This research study aimed at investigating and suggesting the most preferred topics for World Englishes (WE) and Culture course for undergraduate level at ELT department. Therefore, not only providing a syllabus suggestion but also awareness on EFL teachers and teacher trainers 
on how to train their learners on World Englishes and culture was aimed in the study. Being more aware of what to integrate in a syllabus, EFL teachers or teacher trainers could reflect the importance of this elective course whilst raising teacher candidates. To this end, two research questions were reflected and their answers were investigated by means of analyzing various documents and a survey.

The primary research question intended to explore the content of discrete documents which comprised 13 research articles on Google Scholar, two books, 18 documents from Google and 21 university syllabi. Findings demonstrated that 'the effect of culture on language teaching' had the highest percentage which is nearly half of the analysed documents. This finding could be specified as closely related to research studies implemented by Galloway and Rose (2018), Matsuda (2003), and Bayne et al. (2002). In addition to this correlation, this topic was also encouraged by International College of Liberal Arts, University of Florida at Gainesville, Sweden's First University and Northeastern Illinois University. Besides the issue of World Englishes, culture is another important factor to be considered.

The second most-selected topic as a result of content analysis was identified as 'English culture and history'. The selection of this topic for WE and Culture course were suggested by the studies generated by Jenkins (2009), Bayne et al. (2002). Furthermore, this topic was also comprised in the syllabus of institutions such as Norwegian University of Science and Technology, University of Southampton, University of Illinois at Springfield and the University of Edinburgh.

The third most-preferred topic designated by the analysis of the documents was 'Internationalisation: Standards of English', whose significance could be referred to studies conducted by Fang et al. (2017), Llurda (2009) and Sharifian (2009). The importance of this topic could be observed in syllabi of institutions such as Başkent University, Middle East Technology University and Pamukkale University.

Research question two targeted at discovering teacher trainers' order of significance on the 35 topics throughout the survey. As a result of the responses by 63 teacher trainers, the first most-preferred topic for WE and Culture course was selected as 'the effect of culture on language teaching', which certainly designates the same finding by the analysis of the documents. Similarly, research studies implemented by Galloway and Rose (2018), Matsuda (2003), and Bayne, Usui and Watanabe (2002) indicate the importance of this point within WE and Culture concern.

The second most-preferred topic for the elective course was identified as 'Introduction: why 'world Englishes'?' by teacher trainers, however analysis of the documents demonstrated a contrastive finding (2\%). 'Raising awareness on WE and Culture' was obtained as the third most-preferred topic by teacher trainers, which demonstrates a similar result with the analysis of the documents. This topic was additionally encouraged by studies implemented by Galloway and Rose (2018) and Tanghe (2014). Another important aspect of this research study could be that it involves some contents which designate teacher candidates a practical notion on how to apply World Englishes and culture course through discrete materials and within various learning environments. In addition, the order of contents comprised in the suggested syllabus could be distinctive depending on objectives or needs. However, it has been considered that any of these contents could provide teacher candidates with a distinct notion of the 'World Englishes' issue. 
In addition to the statements above, one further highlighting finding was obtained as a result of the open-ended item in the survey. This finding indicated that there were two teacher trainers who argued that learners need to acquire a sociolinguistics background prior to taking WE and Culture course at undergraduate level.

\section{Implications}

In terms of constituting a syllabus for WE and Culture as an elective course, teacher trainers' views and perceptions of discrete topics could be taken into consideration. In accordance with this notion, a categorization of topics obtained from the analysis of the documents could be convenient prior to providing teacher trainers with a group of topics to select. In addition to this, further course syllabi should come into prominence and their contents need to be analyzed so that teacher trainers could be supplied with a greater number of alternative elective courses.

Considering the findings obtained as a result of this study, it could be appropriate to suggest 'The effect of culture on language teaching' as an initial topic for WE and Culture course since it was the most-preferred concern by both documents and teacher trainers. Furthermore, 'Introduction: why 'world Englishes'?' and 'Raising awareness on WE and Culture' could be selected as essential topics for WE and Culture course. In addition, since topics the mean values of which were over 4.20 were closely related to World Englishes and Culture, the topics might be crucial to consider while forming a suggested syllabus (See Appendix). Furthermore, teacher trainers' needs and their learners' grade at university may be discrete. Therefore, it could be convenient to implement a needs analysis in addition to the analysis of the documents so as to constitute an ideal and avail syllabus for their elective course.

A further implication could be specified for researchers who plan to conduct research studies on the constitution of a course syllabus. It could be highly suggested to utilize both qualitative and quantitative means of data collection so that they could obtain richer data to constitute a survey and explore participants' responses.

A final implication could be identified in terms of the items which were incorporated in the survey. To explain, there could have been an extra item which questions whether such a 'WE and Culture' selective course is needed for undergraduate ELT learners. This implementation is considered to shed light on future research studies which intend to explore and design a syllabus and constitute a survey for this aim.

\section{Disclosure Statement}

No potential conflict of interest was reported by the authors.

\section{References}

Bayne, K., Usui, Y., \& Watanabe, A. (2002, September). World Englishes and self-images of Japanese: A summary. In 1st Peace as a Global Language Conference Proceedings and Supplement. Tokyo, Japan.

Büyüköztürk, Ş. (2006). Sosyal bilimler için veri analizi el kitabı (6. Bask1). Pegem.

Cogo, A., \& Dewey, M. (2012). Analysing English as a lingua franca: A corpus-driven investigation. Bloomsbury Publishing.

Creswell, J. W. (2014). Research design: Qualitative, quantitative, and mixed methods approaches (4th ed.). Sage Publications, Inc.

Fang, F. G., Hu, L., \& Jenkins, J. (2017). Overseas Chinese students' perceptions of the influence of English on their language and culture. Journal of Asia TEFL, 14(1), 144.

Galloway, N., \& Rose, H. (2018). Incorporating global Englishes into the ELT classroom. ELT Journal, 72(1), 3-14. 
Hemmati, F., \& Mojarrad, H. (2016). E-learning and Distance Education: A Study of Iranian Teaching English as a Foreign Language Masters Students. Malaysian Journal of Distance Education, 18(1).

Ivankova, N. V., Creswell, J. W., \& Stick, S. L. (2006). Using mixed methods sequential explanatory design: From theory to practice. Field Methods, 18(1), 3-20.

Jenkins, J. (2009). English as a lingua franca: Interpretations and attitudes. World Englishes, 28(2), 200-207.

Kachru, Y. (1985). Discourse analysis, non-native Englishes and second language acquisition research. World Englishes, 4(2), 223-232.

Kachru, B. B., \& Nelson, C. (2001). World Englishes. In A. Burns \& C. Coffin (Eds.), Analysing English in a global context (pp. 5-17). Routledge.

Kuo, I. C. (2006). Addressing the issue of teaching English as a lingua franca. ELT journal, 60(3), 213-221.

Llurda, E. (2009). Attitudes towards English as an international language: The pervasiveness of native models among L2 users and teachers. In F. Sharifian (Ed.), English as an international language: Perspectives and pedagogical issues, (pp. 119-134). Multilingual Matters.

Lune, H. \& Berg, B. L. (2017). Qualitative research methods for social sciences (9th ed.). Vivar, Malaysia: Pearson.

Matsuda, A. (2003). Incorporating world Englishes in teaching English as an international language. Tesol Quarterly, 37(4), 719-729.

Meyer, D. Z. \& Avery, L. M. (2009). Excel as a Qualitative Data Analysis Tool. Field Methods, 21(1), 91-112.

Sharifian, F. (Ed.). (2009). English as an international language: Perspectives and pedagogical issues (Vol. 11). Multilingual Matters.

Sridhar, S. N. (1982). Non-native English literatures: context and relevance. In B. B. Kachru (Ed.), The other tongue: English across cultures, (pp. 291-306). Urbana: University of Illinois Press.

Tanghe, S. (2014). Integrating World Englishes into a university conversation class in South Korea: Practical suggestions and theoretical reflections for bringing World Englishes into EFL classrooms. English Today, 30(2), 18-23.

\section{Appendix}

Suggested Syllabus for World Englishes and Culture Elective Course

\begin{tabular}{ll}
\hline Weeks & Topics \\
\hline 1. & Introduction of course content, structure, tasks, and assessment \\
2. & Importance of Sociolinguistics for WE and Culture \\
3. & Why 'world Englishes'? \\
4. & The effect of culture on language teaching \\
5. & How to analyze cultural elements in language teaching materials. \\
6. & The use of English as an International Language EIL \\
7. & Language-related issues emerging from global English contexts \\
8. & Discuss and Assign Examples of World Englishes for Week $12 \& 13$ \\
9. & Midterm \\
10. & Communicative competence \\
11. & Raising awareness on WE and culture - Awareness of diversity in learning environments \\
12. & and adapting to different local contexts \\
13. & Debates - Oral presentation of Examples of World Englishes \\
14. & Debates - Oral presentation of Examples of World Englishes
\end{tabular}

\section{Copyrights}

Copyrights for the articles are retained by the author(s), with first publication rights granted to the Journal.

This is an open-access article distributed under the terms and conditions of the Creative Commons Attribution license (CC BY-NC-ND). https://creativecommons.org/licenses/by-nc-nd/4.0/ 